IZVORNI RAD

UDK: 519.83:37

Marina Slišković, mag. math. *

Doc. dr. sc. Tunjo Perić **

\title{
SHAPLEYEVA VRIJEDNOST KAO MJERA DRUŠTVENE KORISNOSTI OBRAZOVNE RAZINE I USMJERENJA
}

\author{
SHAPLEYE'S VALUE AS A MEASURE OF SOCIAL BENEFITS \\ OF EDUCATIONAL LEVELS AND ORIENTATIONS
}

\begin{abstract}
SAŽETAK: Shapleyjeva vrijednost je poznati koncept kooperativne teorije igara koji predstavlja jedinu raspodjelu ukupne korisnosti koju su postigli igrači u koaliciji, a koja zadovoljava tzv. Shapleyjeve aksiome pravedne raspodjele. Barakat, B. i Crespo Cuaresma, J. (2017.) predlažu uporabu Shapleyjeve vrijednosti kao pravednu mjeru korisnosti triju razina obrazovanja za društvo. Za razliku od uobičajenih kvantitativnih ocjena vrijednosti pojedine obrazovne razine, Shapleyjeva vrijednost uzima u obzir nužnost stjecanja nižih razina obrazovanja kao preduvjeta za stjecanje viših. U ovome radu se njihov model primjenjuje za ocjenu vrijednosti obrazovnih razina za pojedinca u Hrvatskoj, ali i za gospodarstvo Republike Hrvatske u cjelini. Dodatno, poopćuje se njihov rezultat na hijerarhijsku strukturu s proizvoljno mnogo razina te se također proširuje na način da se zasebno proučavaju vrijednosti različitih usmjerenja na najvišoj obrazovnoj razini uz dokaz da primijenjena formula predstavlja upravo Shapleyjevu raspodjelu vrijednosti koalicije. Novi model je primijenjen za procjenu vrijednosti obrazovnih razina za gospodarstvo Republike Hrvatske.
\end{abstract}

KLJUČNE RIJEČI: Kooperativna teorija igara, Shapleyjeva vrijednost, vrijednost obrazovnih razina.

ABSTRACT: Shapley's value is a well-known concept of cooperative game theory that represents the only distribution of overall utility achieved by players in the coalition, which satisfies the so-called Shapley's Axioms of fair division. Barakat, B. And Crespo Cuaresma, J. (2017) suggest the use of Shapley's values as a fair measure of the benefit of three levels of education for society. Unlike the usual quantitative estimates of the benefit of a particular educational level, Shapley's value takes into account the necessity of acquiring lower levels of education as a precondition for acquiring higher education. In this paper, their model is applied to assess the value of each educational level for the individual in Cro-

Marina Slišković, mag. math., Ekonomski fakultet Sveučilišta u Zagrebu, Trg J. F. Kennedyja 6, Zagreb, msliskovic@efzg.hr

** Doc. dr. sc. Tunjo Perić, Ekonomski fakultet Sveučilišta u Zagrebu, Trg J. F. Kennedyja 6, Zagreb, tperic@ efzg.hr 
atia, as well as for the Croatian economy as a whole. Additionally, we generalize their result to a hierarchical structure with arbitrarily many levels and, additionally, to a model that distinguishes the value of different orientations at the highest educational level. The proof that the applied formula represents Shapley's distribution of coalition value is also given. A new model is used to assess the utility of educational levels for the Croatian economy.

KEYWORDS: Cooperative gama theory, Shapley value, value of education levels.

\section{UVOD}

Pri alokaciji financijskih sredstava osnovna pretpostavka je dobra procjena korisnosti koju će nam donijeti pojedino ulaganje. Shvaćamo li ulaganje u obrazovanje kao ulaganje u gospodarstvo, pri raspodjeli sredstava na pojedine obrazovne razine trebamo na ispravan način procijeniti utjecaj tih obrazovnih razina na gospodarstvo. Unatoč tome, pri kvantificiranju vrijednosti pojedine razine obrazovanja u radovima se uglavnom izučava koliku dodatnu korist možemo ostvariti uz višu razinu obrazovanja, uz konstantne ostale faktore. $\mathrm{Na}$ taj način se previše vrednuje svaka iduća obrazovna razina jer se izostavlja uračunati doprinos nižih razina obrazovanja za one sudionike gospodarstva koji su kasnije stekli viši stupanj obrazovanja odnosno izostavlja se uvažiti nužnost stjecanja nižih razina obrazovanja kao preduvjeta za stjecanje viših.

Iako se na taj način može procijeniti očekivani prihod koji će imati pojedinac za svaku dodatnu godinu obrazovanja (uz iste ostale osobne karakteristike), nije prikladan za procjenu korisnosti obrazovanja za gospodarstvo. Pri procjeni vrijednosti obrazovnih razina za gospodarstvo potrebno je uvažiti hijerarhijsku strukturu obrazovanja u smislu da je nužno prvo steći osnovno obrazovanje kako bi se nakon njega steklo srednje i u konačnici visoko obrazovanje.

Kao što je već spomenuto, u prošlosti su se autori uglavnom usredotočavali na dodatnu vrijednost koju ima pojedinac od dodatne razine obrazovanja i to u obliku dodatnih očekivanih budućih primanja (Weisbrod, 1962.). Iako je takav pristup često kritiziran jer nedovoljno vrednuje niže obrazovne razine (Colclough et al., 2010.) zbog nepostojanja modela koji bi uzeli u obzir hijerarhijsku strukturu obrazovanja, takvi su se modeli zadržali i često se koriste i danas. Dodatni nedostatak takvih modela je pretpostavka o konstantnim ostalim osobnim karakteristikama pri interpretaciji rezultata. Barakat et al. (2017.) ističu kako su za uspjeh koji postižu visokoobrazovani pojedinci barem djelomično zaslužne njihove osobne karakteristike, a ne samo isključivo dodatne godine ili razine obrazovanja. Uključivanje osobnih karakteristika u model obrazovanja izaziva niz metodoloških problema pa ih zbog toga ne uključujemo u naš model.

U ovome se radu daje jedan mogući pristup iz područja kooperativne teorije igara za vrednovanje obrazovnih razina koji uzima u obzir postojeću hijerarhijsku strukturu obrazovanja. Nadalje, cilj rada je proširiti ovu teoriju na način da se najviša obrazovna razina raščlani na više sastavnica koje međusobno nemaju hijerarhijsku strukturu te iznijeti podatke za Republiku Hrvatsku.

U prvome dijelu rada iznesene su osnovne definicije i rezultati iz područja Kooperativne teorije igara koji su potrebni za aplikativni dio rada (Shapley, 1953.). U idućemu se razmatra primjena modela koji predlažu Barakat i Cuaresma (2017.) za vrednovanje obrazovnih razina (Metodologija nacionalne standardne klasifikacije obrazovanja, 2001.) 
primjenom Shapleyjeve vrijednosti za vrednovanje korisnosti obrazovnih razina za gospodarstvo Republike Hrvatske. Također, predlaže se na koji način bi se isti model mogao primijeniti i za vrednovanje osobne koristi od obrazovanja. U trećemu dijelu rada se predlaže poopćenje modela kako bi se mogla ocijeniti korisnost različitih visokoobrazovnih razina. U istome je dijelu dan izvod formule koja se primjenjuje u kvantificiranju korisnosti, tj. dokazano je da se zaista radi o Shapleyjevoj vrijednosti. Konačno, u zadnjemu dijelu dani su zaključci i prijedlozi za buduća istraživanja.

\section{KOOPERATIVNA TEORIJA IGARA I SHAPLEYJEVA VRIJEDNOST}

Kooperativna teorija igara pretpostavlja da ne postoje nikakva ograničenja u formiranju koalicija među igračima te da igrači teže maksimizaciji individualne korisnosti kroz maksimizaciju zajedničke korisnosti (Ferguson, 2014., Bird, 1976.).

Neka je zadana igra s $n \geq 2$ igrača i neka je skup igrača $N=\{1,2, \ldots, n\}$. Koalicija je bilo koji podskup skupa igrača, $S \subset N$, tj. bilo koji element partitivnog skupa $P(\mathbb{N})$. Prazan skup $\varnothing$ po konvenciji također smatramo koalicijom i zovemo je prazna koalicija. Skup svih igrača $S=N$ zovemo velika koalicija.

Koalicijski oblik igre $n$ igrača je uređeni par $(N, v)$ gdje je $N=\{1,2, \ldots, n\}$ skup igrača, a $v: \mathrm{P}(\mathbb{N}) \rightarrow \mathbb{R}$ karkteristična funkcija igre koja zadovoljava:

1. $v(\varnothing)=0 \mathrm{i}$

2. superaditivnost: za svaka dva disjunktna skupa $S$ i $T$ (tj. takve da je $S \cap \mathrm{T}=\varnothing$ ) je $v(S \cup T) \geq v(S)+v(T)$. (Shapley, 1953.).

Dakle, karakteristična funkcija mora zadovoljiti dva uvjeta koji se prirodno nameću: prazna koalicija nema vrijednost, a formiranje veće koalicije od dvije manje uvijek daje barem onoliku korisnost koliko iznosi zbroj korisnosti tih manjih koalicija.

Karakteristična funkcija nije nužno jedinstvena. Uobičajeno je stratešku igru više igrača svoditi na koalicijske na način da se za korisnost koalicije uzima minimalna korisnost koju članovi te koalicije mogu osigurati, igrajući zajedno (Ferguson, 2014.).

Ključno pitanje koje se nameće koaliciji je kako raspodijeliti ukupnu ostvarenu korisnost. Raspodjela bi trebala biti pravedna u smislu da udio koji dobiva pojedini igrač odražava njegovu snagu u koaliciji, tj. odražava njegov doprinos koaliciji.

Funkcija vrijednosti $\phi$ je funkcija koja svakoj karakterističnoj funkciji koalicijske igre skupa igrača $N$ dodjeljuje uređenu $n$ - torku realnih brojeva $\left(\phi_{1}(v), \phi_{2}(v), \ldots, \phi_{n}(v)\right)$ pri čemu $\phi_{i}(v)$ predstavlja vrijednost $i$ - tog igrača za koaliciju uz karakterističnu funkciju $v$.

Prirodno se nameću određena ograničenja koja pravedna raspodjela mora zadovoljiti. Ta ograničenja matematički možemo formirati u tzv. Shapleyjeve aksiome pravednosti (Ferguson, 2014.):

1. Efikasnost: $\sum_{i \in N} \phi_{i}(v)=v(N)$

2. Simetričnost: Ako su $i$ i $j$ takvi da je $v(S \cup\{i\})=v(S \cup\{j\}) \quad$ za svaku koaliciju $S$ koja ne sadrži ni $i$ ni $j$, onda je $\phi_{i}(v)=\phi_{j}(v)$. 
3. Nulta korisnost: Ako je $i$ takav da je $v(S \cup\{i\})=v(S)$ za svaku koaliciju $S$ koja ne sadrži $i$, onda je $\phi_{i}(v)=0$.

4. Aditivnost: Ako su $v$ i $u$ karakteristične funkcije, onda je $\phi(u+v)=\phi(u)+\phi(v)$.

Funkcija vrijednosti mora zadovoljavati gornje aksiome pravednosti. Prije svega, za svaku karakterističnu funkciju $v$ raspodjela mora biti efikasna u smislu da se cijela korisnost raspodijeli između članova koalicije, tj. da ne postoji dio ukupne korisnosti koji nikome nije raspodijeljen. Nadalje, ako dva igrača imaju jednaku dodatnu korisnost za svaku moguću koaliciju, pravedna raspodjela bi im trebala dodijeliti jednake iznose. Ako neki igrač ne dodaje korisnost niti jednoj koaliciji, tada bi njegova vrijednost trebala niti nula. Konačno, aksiom aditivnosti nam govori da vrijednost dviju igara koje se igraju istodobno mora biti jednaka zbroju vrijednosti istih tih igara ako se igraju odvojeno. Bitno je napomenuti da, ako su $u$ i $v$ karakteristične funkcije, tada je i $u+v$ karakteristična funkcija.

Moguće je dokazati da postoji jedinstvena funkcija $\phi$ koja zadovoljava gornje aksiome. Za dokaz vidjeti Ferguson (2014.). Vrijednost koju ona dodjeljuje svakom pojedinom igraču, tzv. Shapleyjeva vrijednost, jednaka je:

$$
\phi_{i}(v)=\sum_{\substack{S \in N \\ i \in S}} \frac{(|S|-1) !(n-|S|) !}{n !} \cdot \underbrace{[v(S)-v(S, \quad\{i\})]}_{\text {dodatna vrijednost igrača } i},
$$

gdje $|S|$ označava kardinalni broj, tj. broj elemenata skupa $S$.

Shapleyjeva vrijednost predstavlja prosječnu dodatnu (marginalnu) vrijednost koju donosi pojedini igrač kada pristupa koaliciji. Naime, kako redoslijed pristupanja koaliciji može biti različit, tako i dodatna vrijednost igrača koji pristupa koaliciji ovisi o tome koji su igrači u koaliciji bili prije njega.

Shapleyjeva vrijednost je prosječna dodatna vrijednost igrača kada se gleda po svim mogućim permutacijama igrača.

Primjer 1: Pretpostavimo da $N=\{1,2,3\}$ i neka za karakterističnu funkciju $v$ vrijedi

$$
v(\varnothing)=0, v(\{1\})=-1, v(\{2\})=1, v(\{3\})=2, v(\{1,2\})=1, v(\{1,3\})=2, v(\{2,3\})=5, v(\{1,2,3\})=10 .
$$

Postoji 3 ! = 6 permutacija igrača $1,2,3$ pa se koalicija tih triju igrača može formirati na 6 različitih redoslijeda. U donjoj tablici oznakom ijk označen je redoslijed stvaranja velike koalicije pri čemu je prvo u koaliciju pristupio igrač $i$, zatim mu se pridružio $j$ te konačno $k$. U svakome stupcu je označeno koliki je marginalni doprinos pojedinoga igrača u tome slučaju.

Na primjer, u drugom retku tablice, velika koalicija se formira tako da formiranje započinje igrač broj 1 kojemu se naknadno pridružuje igrač broj 3 te konačno igrač broj 2. Marginalni doprinos igrača 1 u takvome redoslijedu iznosi $v(\{1\})-v(\varnothing)=-1-0=-1$, za igrača 3 iznosi $v(\{1,3\})-v(\{1\})=2-(-1)=3$, a za igrača 2 iznosi $v(\{1,2,3\})-v(\{1,3\})=10-2=8$. 
Tablica 1. Primjer izračuna Shapleyjeve vrijednosti

\begin{tabular}{|l|l|c|c|c|}
\hline & & \multicolumn{3}{|c|}{ Marginalni doprinos igrača } \\
\hline \multirow{5}{*}{ Permutacija } & & $\mathbf{1}$ & $\mathbf{2}$ & $\mathbf{3}$ \\
\cline { 2 - 5 } & $\mathbf{1 2 3}$ & $\mathbf{- 1}$ & 2 & 9 \\
\cline { 2 - 5 } & $\mathbf{1 3 2}$ & $\mathbf{- 1}$ & 8 & 3 \\
\cline { 2 - 5 } & $\mathbf{2 1 3}$ & 0 & 1 & 9 \\
\cline { 2 - 5 } & $\mathbf{3 1 2}$ & 5 & 1 & 4 \\
\cline { 2 - 5 } & $\mathbf{3 2 1}$ & 5 & 8 & 2 \\
\cline { 2 - 5 } & Prosječno & $\phi_{1}(v)=\frac{8}{6}$ & $\phi_{2}(v)=\frac{23}{6}$ & $\phi_{3}(v)=\frac{29}{6}$ \\
\hline
\end{tabular}

Izvor: izračun autora.

Korištenjem aksioma pravedosti i matematičke indukcije moguće je dokazati da je

$$
\phi_{i}(v)=\sum_{\substack{S \subset N \\ i \in S}} \frac{c_{S}}{|S|}
$$

gdje su konstante $c_{S}$ definirane rekurzivno s $c_{\varnothing}=0$ te

$$
c_{S}=v(\mathrm{~S})-\sum_{\substack{T \subset S \\ T \neq S}} c_{T} .
$$

Dokaz se može pronaći u (Ferguson, 2014., str. 13-17).

Primjer 2: Neka je zadana karakteristična funkcija $v$ kao u primjeru 1. Konstante $c_{S}$ možemo izračunati na temelju jednakosti (2.3). Zbog jednostavnosti zapisa ćemo s $c_{i}$ označavati $c_{\{i\}}$, a s $c_{0}$ ćemo označavati $c_{\varnothing}=0$. Slično, s $c_{i j}$ označavamo $c_{\{i j\}}$ te konačno s $c_{123}$ označavamo $c_{\{1,2,3\}}$.

Kako je $c_{0}=0$, za sve jednočlane skupove $S=\{i\} \subset N$ vrijedi

$c_{i}=v(\{i\})-c_{0}=v(\{i\})$.

U našem primjeru je $c_{1}=v(\{1\})=-1, c_{2}=v(\{2\})=1$ te $c_{3}=v(\{3\})=2$.

Za dvočlane skupove je:

$c_{12}=v(\{1,2\})-c_{1}-c_{2}=1-(-1)-1=1, c_{13}=v(\{1,3\})-c_{1}-c_{3}=2-(-1)-2=1$, te $c_{23}=v(\{2,3\})-c_{2}-c_{3}=5-1-2=2$.

Konačno,

$c_{123}=v(\{1,2,3\})-c_{12}-c_{13}-c_{23}-c_{1}-c_{2}-c_{3}=10-1-1-2-(-1)-1-2=4$. 
Korištenjem izračunatoga možemo izračunati Shapleyjeve vrijednosti za pojedinog igrača:

$$
\phi_{1}(v)=\frac{-1}{1}+\frac{1}{2}+\frac{1}{2}+\frac{4}{3}=\frac{4}{3}=\frac{8}{6}, \phi_{2}(v)=\frac{1}{1}+\frac{1}{2}+\frac{2}{2}+\frac{4}{3}=\frac{23}{6}, \phi_{3}(v)=\frac{2}{1}+\frac{1}{2}+\frac{2}{2}+\frac{4}{3}=\frac{29}{6} .
$$

Iako je u slučaju malog broja igrača ova metoda kompliciranija od računanja prosječnog marginalnog prinosa po svim mogućim permutacijama igrača, u slučaju velikog broja igrača ili u teorijskim analizama može biti korisna.

\section{SHAPLEYEVA VRIJEDNOST ZA PROCJENU KORISNOSTI OBRAZOVNE RAZINE}

Heckman et al. (2005.) i Bečić (2014.) ukazuju na značenje obrazovanja na tržištu rada prema ekonomskoj teoriji. Barakat i Cuaresma (2017.) predlažu uporabu Shapleyjeve vrijednosti kao pravednu mjeru korisnosti razine obrazovanja. Ističu da se u radovima takve procjene uobičajeno vrše regresijskom analizom i interpretiraju se kao dodatna korisnost od dodatne jedinice školovanja, uz konstantne ostale osobne karakteristike te da se na taj način zanemaruje činjenica da su niže razine obrazovanja preduvjet za više razine. To za posljedicu ima nedovoljno vrednovanje nižih razina i pretjerano vrednovanje viših razina obrazovanja.

Neka je s $d_{i}$ označen doprinos $i$ - te razine obrazovanja u odnosu na $(i-1)-\mathrm{u}$ razinu, $i=1,2,3$, gdje nultom razinom obrazovanja smatramo obrazovanje niže od osnovnoškolskoga, prva razina je osnovnoškolsko, druga srednjoškolsko i treća visoko obrazovanje. Doprinosi razina obrazovanja u odnosu na 6 mogućih permutacija su dani u tablici ispod.

Tablica 2. Shapleyjeva vrijednosti za vrednovanje tri razine obrazovanja

\begin{tabular}{|c|c|c|c|c|}
\hline & & \multicolumn{3}{|c|}{ Marginalni doprinos obrazovne razine } \\
\hline \multirow{8}{*}{ Permutacija } & & 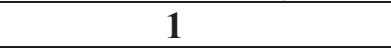 & 2 & 3 \\
\hline & 123 & $d_{1}$ & $d_{2}$ & $d_{3}$ \\
\hline & 132 & $d_{1}$ & $d_{2}+d_{3}$ & 0 \\
\hline & 213 & $d_{1}+d_{2}$ & 0 & $d_{3}$ \\
\hline & 231 & $d_{1}+d_{2}+d_{3}$ & 0 & 0 \\
\hline & 312 & $d_{1}$ & $d_{2}+d_{3}$ & 0 \\
\hline & 321 & $d_{1}+d_{2}+d_{3}$ & 0 & 0 \\
\hline & Prosječno & $\phi_{1}(v)=d_{1}+\frac{1}{2} d_{2}+\frac{1}{3} d_{3}$ & $\phi_{2}(v)=\frac{1}{2} d_{2}+\frac{1}{3} d_{3}$ & $\phi_{3}(v)=\frac{1}{3} d_{3}$ \\
\hline
\end{tabular}

Izvor: prilagodba autora prema Barakat, Crespo Cuaresma (2017.).

Pri tome je pretpostavljano da je vrijednost samo osnovnoga obrazovanja $v(\{1\})=d_{1}$ , vrijednost osnovnoga i srednjega obrazovanja $v(\{1,2\})=d_{1}+d_{2}$ te vrijednost osnovnoga, 
srednjega i visokoga obrazovanja $v(\{1,2,3\})=d_{1}+d_{2}+d_{3}$. Naravno, $v(\varnothing)=0$. Također, za sve ostale podskupove od $N=\{1,2,3\}$ je pretpostavljano da zajedno vrijede 0 . Primjerice, $v(\{2,3\})=0$ jer nije moguće ostvariti vrijednost samo pomoću srednjega i visokoga obrazovanja jer je osnovno obrazovanje preduvjet za srednje obrazovanje. Uz ove pretpostavke, marginalni doprinosi pojedine razine obrazovanja u odnosu na moguće permutacije prikazani su u tablici. Npr., permutacija 213 predstavlja doprinos srednjoškolske razine obrazovanja bez prethodnoga obrazovanja, zatim osnovnoškolske uz prethodno srednjoškolsko te konačno visokoškolskoga obrazovanja uz prethodno srednjoškolsko i osnovnoškolsko. Naravno, nije moguće prvo završiti srednjoškolsko obrazovanje, stoga doprinos razine obrazovanja 2 iznosi $v(\{2\})=0$. Kako je $v(\{1,2\})=d_{1}+d_{2}$, to je marginalni doprinos osnovnoškolskoga obrazovanja za ovu permutaciju jednak $v(\{1,2\})-v(\{2\})=d_{1}+d_{2}-0=d_{1}+d_{2}$. Konačno, ukupna vrijednost svih triju razina obrazovanja iznosi $v(\{1,2,3\})=d_{1}+d_{2}+d_{3}$ te je marginalni doprinos treće razine jednak $v(\{1,2,3\})-v(\{1,2\})=d_{3}$. Slično se popune preostali retci tablice.

Tri razine obrazovanja možemo predočiti kao graf kod kojega su bridom povezane samo dvije uzastopne razine obrazovanja.

Slika 1: Grafički prikaz obrazovnih razina i pripadnih marginalnih korisnosti

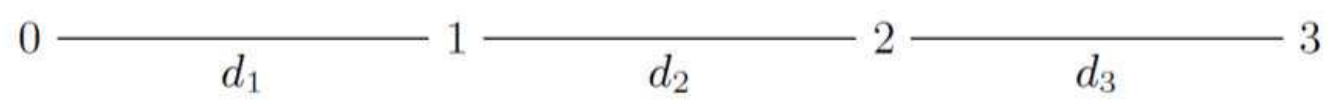

Izvor: izrada autora.

Moguće je promatrati i bilo koju drugu hijerarhijsku strukturu na više razina i na taj način poopćiti ovaj rezultat. Primjerice, svaku dodatnu godinu školovanja možemo smatrati dodatnom obrazovnom razinom.

Slika 1: Grafički prikaz proizvoljne hijerarhijske strukture i pripadnih marginalnih korisnosti

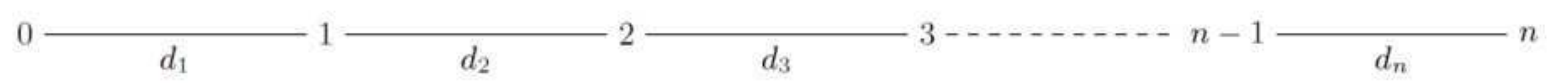

Izvor: izrada autora.

Jednakosti (2.2) i (2.3.) mogu se primjenom matematičke indukcije poopćiti da vrijede za $n$ hijerarhijski uređenih razina, tako da je dodatna korisnost koju nosi razina $i \mathrm{u}$ odnosu na razinu $i-1$ jednaka $d_{i}$. Tada Shapleyjeva vrijednost razine $i$ iznosi

$$
\phi_{i}(v)=\sum_{j \geq i} \frac{d_{j}}{j} .
$$

Primijenimo ovaj model na trenutno važeće podatke u Republici Hrvatskoj. U tablici su dani podaci Državnog zavoda za statistiku o prosječnim mjesečnim isplaćenim neto plaćama po razini obrazovanja (Prosječne mjesečne isplaćene neto i bruto plaće prema stupnju stručne spreme i prema djelatnostima u 2015., 2017.) te broju zaposlenih po stupnju obrazovanja (Zaposlenost i plaće u 2015., 2016.) za 2015. godinu. 
Zbornik Ekonomskog fakulteta u Zagrebu, godina 15, br. 2., 2017.

Tablica 3. Broj zaposlenih i prosječna plaća prema razini obrazovanja u Republici Hrvatskoj

\begin{tabular}{|c|r|r|r|r|r|r|r|r|}
\hline & Visoko & Više & Srednje & VKV & KV & Niže & PKV & NKV \\
\hline $\begin{array}{c}\text { Prosječna } \\
\text { plaća }\end{array}$ & 8.316 & 6.459 & 4.780 & 5.916 & 4.353 & 3.810 & 4.047 & 3.528 \\
\hline $\begin{array}{c}\text { Broj } \\
\text { zaposlenih }\end{array}$ & 233.581 & 87.974 & 511.019 & 12.711 & 75.100 & 26.273 & 14.937 & 56.202 \\
\hline
\end{tabular}

Izvor: izrada autora prema (Prosječne mjesečne isplaćene neto i bruto plaće prema stupnju stručne spreme i prema djelatnostima u 2015., 2017.) i (Zaposlenost i plaće u 2015., 2016.).

Navedene kategorije obrazovanja su spojene u tri skupine. Razinu 1 čine Niža razina obrazovanja, PKV te NKV. Razinu 2 čine Srednja razina obrazovanja te VKV i KV. Konačno, razinu 3 čine Viša i Visoka razina obrazovanja. Temeljem podataka iz tablice, uvažavanjem broja zaposlenih po skupinama, izračunata je ponderirana prosječna neto plaća za ove tri razine i dana je u tablici.

Tablica 4. Prosječna plaća, marginalni doprinos i udio u ukupnoj zaposlenosti prema razini obrazovanja u Republici Hrvatskoj

\begin{tabular}{|l|c|c|c|}
\hline & $\mathbf{1}$ & $\mathbf{2}$ & \multicolumn{1}{|c|}{$\mathbf{3}$} \\
\hline Prosječna plaća $s_{i}$ & $3.683,64$ & $4.750,56$ & $7.807,95$ \\
\hline Doprinos $d_{i}$ & $3.683,64$ & $1.066,92$ & $3.057,38$ \\
\hline Udio u zaposlenosti $r_{i}$ & 0,096 & 0,588 & 0,316 \\
\hline
\end{tabular}

Izvor:izrada autora prema (Prosječne mjesečne isplaćene neto i bruto plaće prema stupnju stručne spreme i prema djelatnostima u 2015., 2017.) i (Zaposlenost i plaće u 2015., 2016.).

Kao što je navedeno ranije, $d_{i}$ označava dodatni iznos koji ostvaruje osoba sa završenom $i$ - tom razinom obrazovanja, u odnosu na osobu koja je završila $(i-1)-\mathrm{u}$ razinu obrazovanja, u ovome slučaju izražena u terminima prosječne neto plaće za pojedinca.

Temeljem formule (3.1) možemo zaključiti da je značaj pojedine razine obrazovanja za osobu sa završenim visokoškolskim obrazovanjem prosječno dan sa:

$$
\phi_{1}(v)=d_{1}+\frac{1}{2} d_{2}+\frac{1}{3} d_{3}=5236,23, \phi_{2}(v)=\frac{1}{2} d_{2}+\frac{1}{3} d_{3}=1552,59 \text { i } \phi_{3}(v)=\frac{1}{3} d_{3}=1019,13 \text {. }
$$

Primijetimo da je zaista $\phi_{1}(v)+\phi_{2}(v)+\phi_{3}(v)=v(\{1,2,3\})=7.807,95, \mathrm{tj}$. ukupna korisnost svih razina predstavlja vrijednost prosječne plaće na razini 3 s najvišim stupnjem obrazovanja (vrijednost velike koalicije za pojedinca).

Kako se moglo vidjeti iz formule (3.1) za prosječnu visokoobrazovanu osobu najveću korisnost ima primarno obrazovanje. Model primarnom obrazovanju pripisuje cijelu prosječnu plaću osobe primarne obrazovne razine, ali i udjele prosječnih plaća viših razina. Za podatke u Hrvatskoj, ovakav model vrednuje prvu obrazovnu razinu s više od 67\%, drugu s gotovo $20 \%$, a treću s nešto više od $13 \%$.

Kod vrednovanja obrazovanja se u ekonomskoj teoriji osim interne korisnosti (korisnost za pojedinca) često izučava i korisnost obrazovanja za društvo (Bečić, 2014.). Za 
procjenu društvene korisnosti treba uvažiti veličinu pojedine obrazovne razine u ukupnome broju zaposlenih. U tu svrhu marginalnim doprinosom pojedine razine obrazovanja možemo smatrati marginalni doprinos te razine u ponderiranoj prosječnoj plaći što odgovara umnošku udjela radnika te razine obrazovanja $r_{i}$ i odgovarajuće prosječne plaće $s_{i}$.

Tablica 5. Ponderirani marginalni doprinos prema razini obrazovanja u Republici Hrvatskoj

\begin{tabular}{|l|c|c|c|}
\hline & $\mathbf{1}$ & $\mathbf{2}$ & $\mathbf{3}$ \\
\hline Ponderirani doprinos $\tilde{d}_{i}$ & 352,56 & $2.795,04$ & $2.466,78$ \\
\hline
\end{tabular}

Izvor: izrada autora prema (Prosječne mjesečne isplaćene neto i bruto plaće prema stupnju stručne spreme i prema djelatnostima u 2015., 2017.) i (Zaposlenost i plaće u 2015., 2016.).

Uvrštavanjem ponderiranih doprinosa $\tilde{d}_{i}=s_{i} \cdot r_{i}$ u (3.1) dobijemo značaj pojedine razine obrazovanja za društvo:

$$
\tilde{\phi}_{1}(v)=2.572,34, \tilde{\phi}_{2}(v)=2.219,78, \tilde{\phi}_{3}(v)=822,26 \text {. }
$$

Primijetimo da je zaista $\tilde{\phi}_{1}(v)+\tilde{\phi}_{2}(v)+\tilde{\phi}_{3}(v)=5.614,37$, što je prema navedenim podacima upravo jednako prosječnoj hrvatskoj neto plaći. ${ }^{1}$

Ovaj pristup vrednovanja razina obrazovanja kao izvoru korisnosti za društvo daje prvoj obrazovnoj razini najveću postotnu važnost u ukupnome doprinosu obrazovanja (45.82\%), a nešto manji drugoj obrazovnoj razini (39.54\%) te neznatno manji značaj trećoj obrazovnoj razini $(14.64 \%)$.

\section{SHAPLEYEVA VRIJEDNOST KAO MJERA DRUŠTVENE KORISNOSTI VISOKOŠKOLSKOG USMJERENJA}

U nastavku rada ćemo proširiti ovako definiran model na način da se promatra više opcija na istoj razini obrazovanja te će se dati dokaz za formulu kojom se može izračunati Shapleyjeva korisnost pojedine razine u takvome modelu.

Primjerice, prema Metodologiji nacionalne standardne klasifikacije obrazovanja (Metodologija nacionalne standardne klasifikacije obrazovanja, 2001.), Državni zavod za statistiku razlikuje tri razine obrazovanja nakon srednjoškolskog: (1) obrazovanje nakon srednjeg koje nije ni više ni visoko, (2) više i visoko obrazovanje i (3) magisterij i doktorat. Treći stupanj obrazovanja možemo promatrati kao lepezu mogućnosti i tako da ga raščlanimo po različitim mogućim usmjerenjima ili na neki drugi način, s time da on mora biti podijeljen na način da nema hijerarhijske strukture, kako bi se mogao primijeniti navedeni model.

Zbog blage vremenske neusklađenosti podatak o broju zaposlenih koji su preuzeti iz (11) i iznosu prosječnih plaća iz (8), prosječna plaća koja se dobije kao ponderirani prosjek prosječnih plaća temeljem ovih podataka u manjoj mjeri odstupa od prosječne plaće iz (8). Zbog nedostupnosti podataka o broju zaposlenih po razini obrazovanja u (8) nije bilo moguće iskoristiti samo te podatke. 
Slika 3: Grafički prikaz raščlanjene najviše obrazovne razine na usmjerenja i pripadnih marginalnih korisnosti

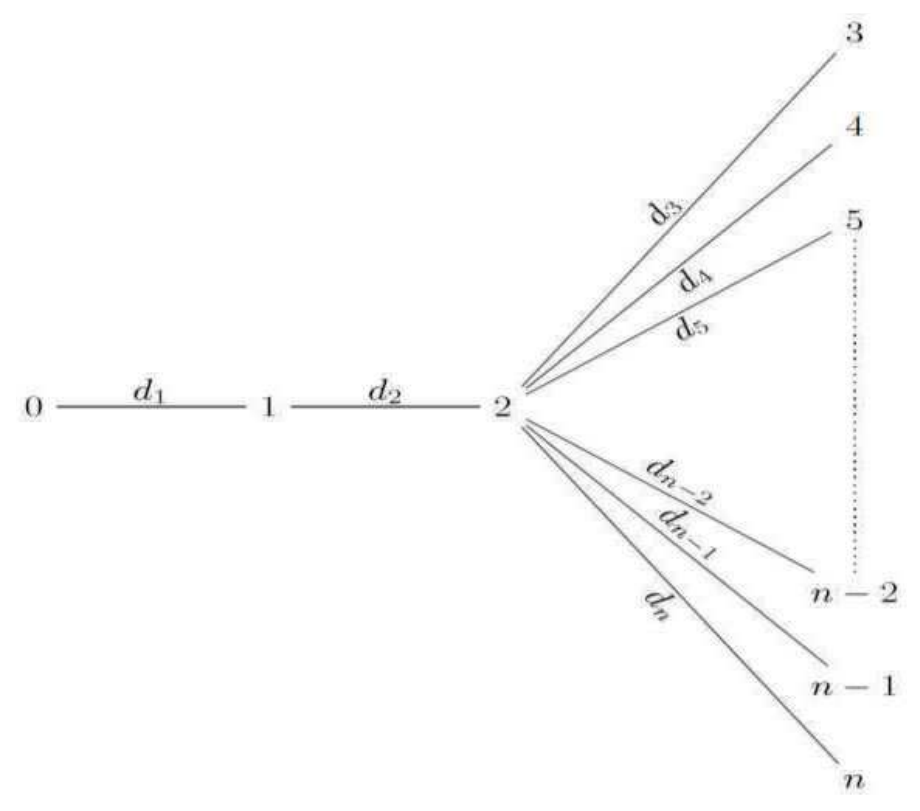

Izvor: izrada autora.

Očigledno za graf prikazan na slici za svaki $S \subset N$ vrijedi

$$
v(\mathrm{~S})= \begin{cases}\sum_{i \in T} d_{i}, & \text { ako je } \mathrm{S} \cap\{1,2\}=\{1,2\} \\ d_{1}, & \text { ako je } \mathrm{S} \cap\{1,2\}=\{1\} \\ 0, & \text { inace. }\end{cases}
$$

Izračunajmo konstante $c_{S}$ iz jednakosti (2.2). Očito je $c_{\{1\}}=d_{1}$ i $c_{\{i\}}=0$ za svaki $i \geq 2$. Za dvočlane skupove $S$ koji sadrže 1 vrijedi:

$c_{\{1,2\}}=v(\{1,2\})-c_{1}-c_{2}=d_{1}+d_{2}-d_{1}-0=d_{2}$ te $c_{\{1, i\}}=v(\{1, i\})-c_{1}-c_{i}=d_{1}-d_{1}-0=0$ za sve $i \geq 3$.

Pokažimo matematičkom indukcijom da je $c_{S}=0$ za sve Skoji ne sadrže 1 . Već smo pokazali da to vrijedi za sve jednočlane skupove $S \subset N$. Pretpostavimo da tvrdnja vrijedi za sve skupove $T$ takve da je $|\mathrm{T}| \leq k$, za neki $k \in N$. Promotrimo sada proizvoljan $(k+1)-$ član skup $S$. Vrijedi

$$
c_{S}=v(\mathrm{~S})-\sum_{\substack{T \subset S \\ T \neq S}} c_{T}=0,
$$

budući je $v(\mathrm{~S})=0$ te je po pretpostavci $c_{T}=0$ za sve prave podskupove $T$ od $S$. Time smo dokazali tvrdnju.

Dokažimo sada da je $c_{S}=0$ za sve skupove $S$ takve da je $|S| \geq 2$ takve da je $S \cap\{1,2\}=\{1\}$. Tvrdnju smo već dokazali za bazu (dvočlani skupovi $S=\{1, i\}$ ). Pretpostavimo da tvrdnja vrijedi za sve skupove $T$ takve da je ITI $\leq k$ za neki prirodan broj $k$. Za $(k+1)-$ član skup $S$ je $v(\mathrm{~S})=d_{1}$ te je stoga, zbog pretpostavke, 


$$
c_{S}=v(\mathrm{~S})-\sum_{\substack{T \subset S \\ T \neq S}} c_{T}=d_{1}-d_{1}=0
$$

budući da je jedini jednočlan podskup skupa $S$ za kojega $c_{T}$ nije 0 skup $\{1\}$, a za sve dvočlane i višečlane prave podskupove od $S$ je $c_{T}=0$ po bazi i pretpostavci indukcije. Time je tvrdnja dokazana.

Konačno, proučimo skupove $S$ takve da je $S \cap\{1,2\}=\{1,2\}$. Već smo pokazali da je $c_{\{1\}}=d_{1}, c_{\{1,2\}}=d_{2}$ te $c_{\{1, i\}}=0$ za sve $i \geq 3$. Zbog toga je za tročlane skupove $S=\{1,2, k\}$ zadovoljeno:

$$
c_{S}=v(\mathrm{~S})-\sum_{\substack{T \subset S \\ T \neq S}} c_{T}=\left(d_{1}+d_{2}+d_{k}\right)-c_{\{1,2\}}-c_{\{1\}}=d_{k}
$$

Za sve višečlane skupove $S$ ( tj. $|\mathrm{S}| \geq 4$ ) dokažimo matematičkom indukcijom da je $c_{S}=0$.

Dokažimo prvo tvrdnju za bazne četveročlane skupove $S=\{1,2, k, l\}$.

$$
c_{S}=v(\mathrm{~S})-\sum_{\substack{T \subset S \\ T \neq S}} c_{T}=\left(d_{1}+d_{2}+d_{k}+d_{l}\right)-c_{\{1,2, k\}}-c_{\{1,2, l\}}-c_{\{1,2\}}-c_{\{1\}}=0 .
$$

Pretpostavimo da tvrdnja vrijedi za sve skupove $T$ takve da je $|\mathrm{T}| \leq k$, za neki $k \in \mathrm{N}$. Promotrimo sada proizvoljan $(k+1)$ član skup $S$.

Vrijedi

$$
c_{S}=v(\mathrm{~S})-\sum_{\substack{T \subset S \\ T \neq S}} c_{T}=\sum_{i \in T_{S}} d_{i}-\sum_{\substack{i \in T_{s} \\ i \geq 3}} c_{\{1,2, i\}}-c_{\{1,2\}}-c_{\{1\}}=\sum_{i \in T_{s}} d_{i}-\sum_{\substack{i \in T_{s} \\ i \geq 3}} d_{i}-d_{2}-d_{1}=0
$$

Konačno, primjenom formule (2.2) dobijemo:

$$
\phi_{1}(v)=d_{1}+\frac{1}{2} d_{2}+\frac{1}{3} \sum_{i \geq 3} d_{i}, \phi_{2}(v)=\frac{1}{2} d_{2}+\frac{1}{3} \sum_{i \geq 3} d_{i}, \phi_{i}(v)=\frac{1}{3} d_{i}, i \geq 3 .
$$

Ovakav model može biti prikladan za procjenu ukupne korisnosti pojedine kategorije visokoga obrazovanja za društvo. Primjerice, možemo procijeniti ponderirane ukupne korisnosti koje za društvo ima pojedino usmjerenje visokoga obrazovanja. Zbog nedostatnosti takvih podataka, demonstrirat ćemo uporabu ovoga modela za procjenu ukupne korisnosti Više obrazovne razine i Visoke obrazovne razine koja se ne može smatrati strogo hijerarhijski uređenom budući da niti jedna od tih razina nije nužan preduvijet za drugu. U tome smislu ih možemo smatrati različitim sastavnicama iste razine obrazovanja. 
Slika 4: Grafički prikaz raščlanjene najviše obrazovne razine na više i visoko obrazovanje i pripadnih marginalnih korisnosti

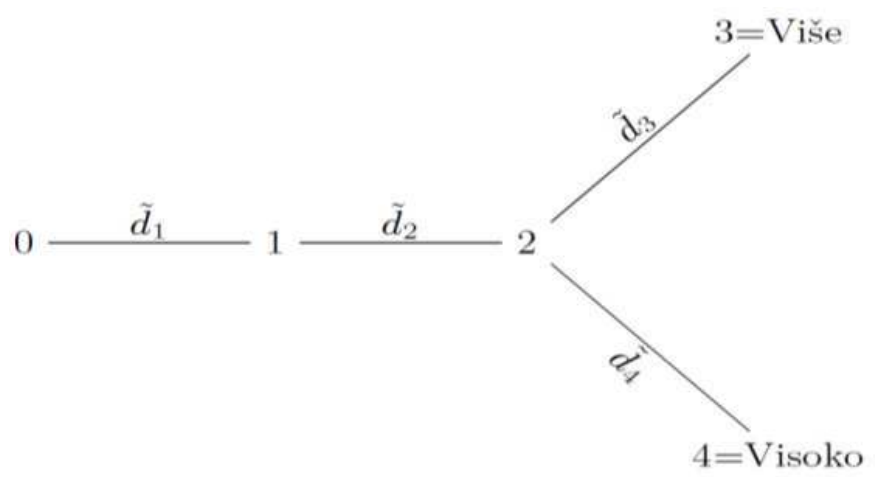

Izvor: izrada autora.

Tablica 6. Prosječna plaća, marginalni doprinos i udio u ukupnoj zaposlenosti prema 4 razine obrazovanja u Republici Hrvatskoj

\begin{tabular}{|l|c|c|c|c|}
\hline & 1 & 2 & 3 & 4 \\
\hline Prosječna plaća $s_{i}$ & $3.683,64$ & $4.750,56$ & $6.459,00$ & 8316,00 \\
\hline Udio u zaposlenosti $r_{i}$ & 0,096 & 0,588 & 0,086 & 0,229 \\
\hline Ponderirani doprinos $\tilde{d}_{i}$ & 352,56 & $2.795,04$ & 558,29 & $1.908,49$ \\
\hline
\end{tabular}

Izvor: izračun autora prema podacima iz Izrada autora prema (Prosječne mjesečne isplaćene neto i bruto plaće prema stupnju stručne spreme i prema djelatnostima u 2015., 2017.) i (Zaposlenost i plaće u 2015., 2016.).

Iz ovih podataka lako izračunamo:

$$
\begin{gathered}
\tilde{\phi}_{1}(v)=\tilde{d}_{1}+\frac{1}{2} \tilde{d}_{2}+\frac{1}{3} \tilde{d}_{3}+\frac{1}{3} \tilde{d}_{4}=2.572,34, \tilde{\phi}_{2}(v)=\frac{1}{2} \tilde{d}_{2}+\frac{1}{3} \tilde{d}_{3}+\frac{1}{3} \tilde{d}_{4}=2.219,78 \\
\tilde{\phi}_{3}(v)=\frac{1}{3} \tilde{d}_{3}=186,10 \text { te } \tilde{\phi}_{4}(v)=\frac{1}{3} \tilde{d}_{4}=636,16 .
\end{gathered}
$$

Primjetimo da je značaj 1. i 2. razine obrazovanja za društvo ostao jednak kao u modelu u kojemu 3. razinu promatramo kao jedinstvenu cjelinu, ali smo treću razinu raščlanili na dva paralelna stupnja obrazovanja od kojih svaki ima svoj značaj. Tako je prema ovome modelu, obzirom na marginalni doprinos u prosječnoj plaći u Republici Hrvatskoj (koji je uvelike određen udjelom zaposlenih te obrazovne razine u svim zaposlenima u Hrvatskoj), značaj višeg obrazovanja ocjenjen s 3,31\%, a značaj visokog obrazovanja s 11,33\%.

Ovakva analiza bi se mogla napraviti i na način da se raščlani doprinos svakog pojedinog visokoškolskog usmjerenja, ali nije prikladna za procjenu individualne korisnosti budući da je pretpostavka Shapleyjevog modela da je zbroj svih Shapleyjevih vrijednosti jednaka vrijednosti velike koalicije. Kako je nemoguće da jedna osoba stekne visokoškolsko obrazovanje iz svih mogućih usmjerenja, takva bi analiza bila besmislena.

Treba napomenuti kako se za primjenu ovoga modela pretpostavlja poznavanje marginalnih korisnosti pojedine obrazovne razine odnosno visokoškolskog obrazovnog usmjerenja u odnosu na neki kriterij. Osim na temelju prosječne neto plaće, moguće je ocijeniti 
značaj pojedine obrazovne razine i temeljem nekih drugih kriterija kao što je prosječna bruto dodana vrijednost po radniku određene obrazovne razine ili prosječna produktivnost rada po radniku određene obrazovne razine. Svaka od tih veličina treba biti ponderirana udjelom radnika te obrazovne razine nakon čega je potrebno izračunati koliki je dodatni doprinos te razine u odnosu na prethodnu (kao što je napravljeno u primjeru).

\section{ZAKLJUČAK}

Prilikom vrednovanja korisnosti obrazovne razine za društvo nužno je uzeti u obzir da su niže razine obrazovanja neophodne za pristupanje višim razinama, što uobičajeni ekonometrijski modeli izostavljaju uvažiti. U ovome radu su, na temelju jednog modela za vrednovanje razina obrazovanja koji temeljem Shapleyjeve vrijednosti uvažava tu hijerarhijsku strukturu, procijenjeni podaci za Republiku Hrvatsku. Obzirom na prosječnu plaću u Republici Hrvatskoj i udjel radne snage sa završenom pojedinom razinom obrazovanja, za hrvatsko gospodarstvo najveći značaj ima prva razina obrazovanja (oko 45\%), zatim druga razina (oko 40\%) te konačno treća razina s oko $15 \%$. Također, predložen je potpuno novi model kojime se mogu zasebno ocijeniti korisnosti pojedinog visokoškolskog obrazovnog usmjerenja za gospodarstvo i dan je dokaz formule kojom se takav doprinos može izračunati temeljem poznatih marginalnih korisnosti pojedine obrazovne razine odnosno usmjerenja. Temeljem tog modela, značaj visokoškolskog obrazovanja je raščlanjen na značaj višeg $(3,31 \%)$ i visokog obrazovanja (11,33\%). U radu su za marginalne korisnosti uporabljene razlike u prosječnim neto plaćama između pojedinih obrazovnih razina, ponderiranih udjelom radnika te obrazovne razine u broju svih zaposlenih u Republici Hrvatskoj. Moguće je uzeti i neke druge kriterije kao što je primjerice, ponderirana prosječna bruto dodana vrijednost po radniku određene obrazovne razine ili prosječna ponderirana produktivnost rada, što ostavljamo za buduća istraživanja. Treba istaknuti da je predloženi model ograničen samo na raslojavanje i izučavanje doprinosa samo najviše obrazovne razine na gospodarstvo. U budućim istraživanjima zanimljivo bi bilo istražiti može li se temeljem Shapleyjeve vrijednosti zasebno vrednovati doprinos različitih obrazovnih usmjerenja i na nižim obrazovnim razinama.

\section{LITERATURA:}

1. Barakat, B., Crespo Cuaresma, J. (2017). Credit Where Credit Is Due: An Approach to Education Returns Based on Shapley Values. Education Economics, 25 (5), 533-541.

2. Bečić, M. (2014.). Značaj obrazovanja na tržištu rada prema ekonomskoj teoriji. Ekonomska misao i praksa: časopis Sveučilista u Dubrovniku, XXIII (1), 213-232.

3. Bird, C. G. (1976). On cost allocation for a spanning tree: A game theoretic approach. Networks, 6(4), 335-350.

4. Colclough, C., Kingdon, G., Patrinos., H. A. (2010). The Changing Pattern of Wage Returns to Education and Its Implications. Development Policy Review, 28(6), 733747. 
5. Ferguson, T. S. (2014). Game Theory Part IV.: Games in Coalitional Form. Dostupno na: https://www.math.ucla.edu/ tom/Game_Theory/coal.pdf [15. srpnja 2017.].

6. Heckman, J. J., Lochner, L. J., Todd, P. E. (2005). Earnings Functions, Rates of Return, and Treatment Effects: The Mincer Equation and Beyond. Handbook of the Economics of Education. Dostupno na: http://www.nber.org/papers/w11544.pdf [10. rujna 2017.].

7. Metodologija nacionalne standardne klasifikacije obrazovanja. Narodne novine, br. 105/2001. Dostupno na: https://narodne-novine.nn.hr/clanci/sluzbeni/2001_11_105_ 1734.html [20. rujna 2017.].

8. Prosječne mjesečne isplaćene neto i bruto plaće prema stupnju stručne spreme $i$ prema djelatnostima u 2015. (2017.). Državni zavod za statistiku. Dostupno na: http:// digured.srce.hr/arhiva/42/51915/9-1-5_\%20Prosjecne\%20mjesecne\%20isplacene $\% 20$ neto $\% 20 \mathrm{i} \% 20$ bruto $\% 20$ place $\% 20$ prema $\% 20$ stupnju $\% 20$ strucne $\% 20$ spreme $\% 20 \mathrm{i} \% 20$ po\%20djelatnostima\%20u\%202015.pdf [20. rujna 2017.].

9. Shapley, L. S. (1953). A value for $n$-person games. U: Roth., A.E. (ur.), The Shapley value: essays ih honor of Lloyd S. Shapley (str. 31-40), Cambridge University Press.

10. Weisbrod, B. A. (1962). Education and investment in human capital. Journal of Political Economy 70 (5, Part 2: Investment in Human Beings), 106-123.

11. Zaposlenost i plaće u 2015. (2016.). Državni zavod za statistiku. Dostupno na: https:// www.dzs.hr/Hrv_Eng/publication/2016/SI-1574.pdf [20. rujna 2017.]. 